\title{
PIPRA CAUDATA.
}

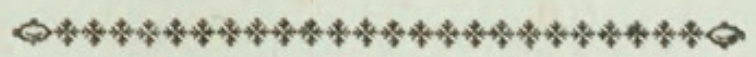

\section{CHARACTER GENERICUS.}

Roftrum capite brevius, bafi fubtrigonum, integerrimum, apice incurvum.

Pedes grefforii.

$$
\text { Lin. Syft. Nat. p. } 338 .
$$

\section{CHARACTER SPECIFICUS.}

PIPRA CÆRULEA, vertice fubcriftato coccineo, alis nigris, rectricibus duabus intermediis elongato-acuminatis.

Colli caudeque latera viridi-splendentia.

Aviculam in fuo genere proculdubio pulcherrimam et coloribus eximiis fuperbientem, fimulque novam nec antea defcriptam, magnitudine naturali depictam, fiftit tabula. In America Auftrali et calidiori, ficut aliæ pleræque congeneres, præcipue invenitur. 

s. 
3ิ

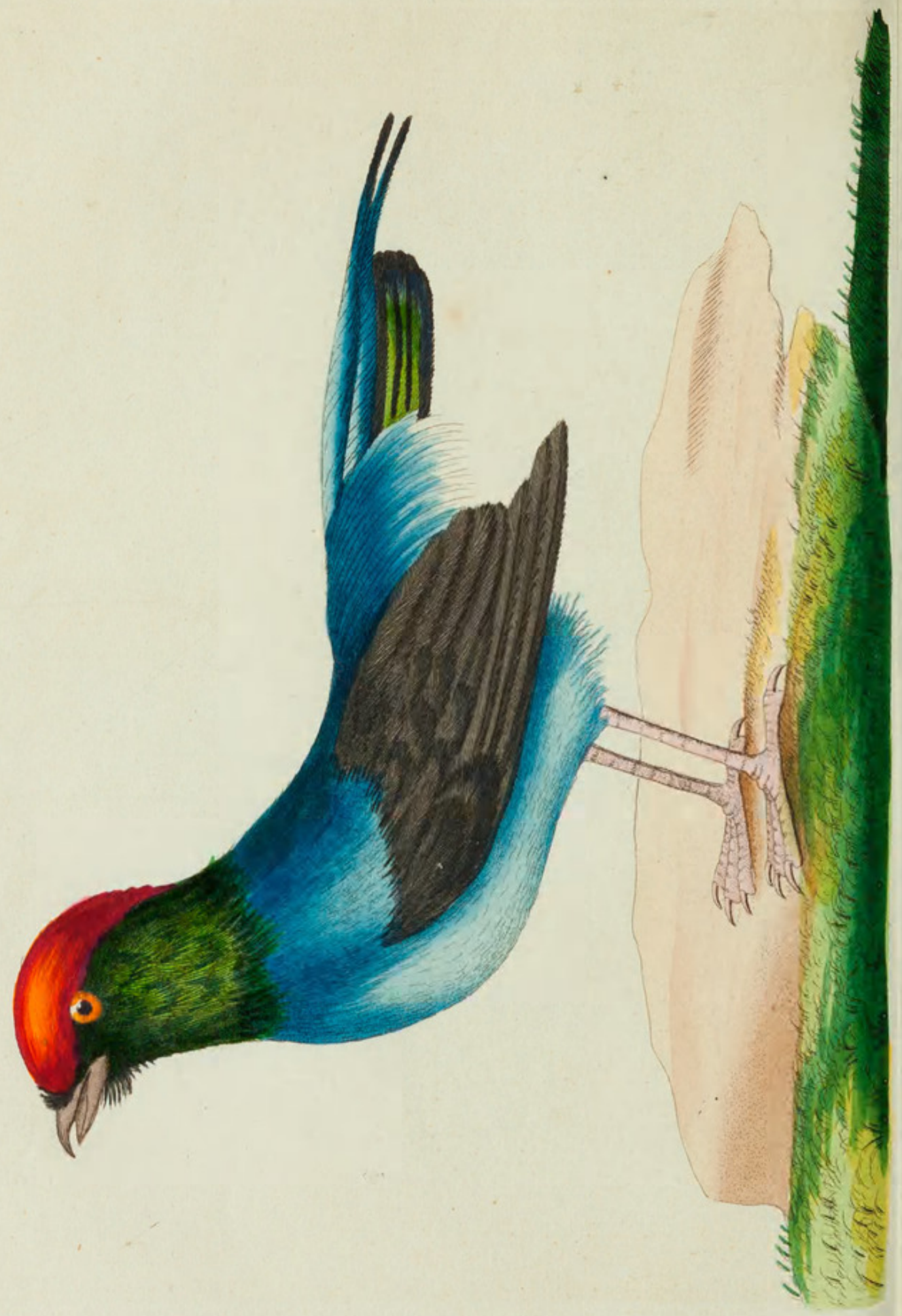




\section{LONG-TAILED MANAKIN.}

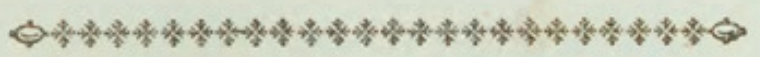

GENERIC CHARACTER.

Bill thorter than the head, fomewhat triangular at the bafe, bent at the tip.

Feet grefforial.

\section{SPECIFIC CHARACTER.}

BLUE MANAKIN with fcarlet crown, black wings, and the two middle tail-feathers elongated and acuminated.

The fides of the neck and tail bave a green luftre.

The bird here reprefented, which is unqueftionably the moft brilliant of its tribe, and is befides a new and hitherto undefcribed fpecies, is figured in its natural fize. Like the reft of its genus it is principally found in the warmer parts of South America. 


\section{$2 \mathrm{BHL}$ Biodiversity Heritage Library}

Shaw, George. 1793. "The Long-Tailed Manakin, Pipra caudata [PI. 153]." The Naturalist's Miscellany 5(L), https://doi.org/10.5962/p.310732.

View This Item Online: https://www.biodiversitylibrary.org/item/276340

DOI: https://doi.org/10.5962/p.310732

Permalink: https://www.biodiversitylibrary.org/partpdf/310732

\section{Holding Institution}

Museums Victoria

\section{Sponsored by}

Atlas of Living Australia

\section{Copyright \& Reuse}

Copyright Status: Public domain. The BHL considers that this work is no longer under copyright protection.

This document was created from content at the Biodiversity Heritage Library, the world's largest open access digital library for biodiversity literature and archives. Visit BHL at https://www.biodiversitylibrary.org. 